\title{
The Economic Logic of Asian Preferential Trade Agreements: The Role of Intra-Industry Trade
}

\author{
Mark S. Manger
}

Are preferential trade agreements (PTAs) in the Asia-Pacific region merely a political phenomenon with no economic basis, as some critics say? I challenge this interpretation; in this article I present an explanatory model based on intra-industry trade to indicate what economic interests should drive Japanese and South Korean PTAs with ASEAN partners, and derive specific predictions. An analysis of the actual tariff barrier elimination in the agreements suggests important, but highly specific, economic benefits. First, preference margins are substantively greater for intra-industry trade, and second, intra-industry trade is much less likely to be excluded from tariff reductions when imported into Japan or South Korea. This indicates that PTAs help firms specialize their production throughout the region, and provides an economic rationale for these agreements. A qualitative case study of the Japan-Malaysia PTA and a statistical analysis of tariff liberalization in the PTAs of Japan and South Korea with the ASEAN countries support this view. KEYWORDS: preferential trade agreements, free trade agreements, Japan, South Korea, ASEAN, intra-industry trade, trade policy

THE BELATED BUT ALL THE MORE VIGOROUS PROLIFERATION OF PREFERENTIAL trade agreements (PTAs) in Asia Pacific has stimulated a flurry of publications in international relations (IR) in recent years (Aggarwal and Urata 2006; Katada, Solís, and Stallings 2009; Katzenstein and Shiraishi 2006; Pekkanen 2005; Pekkanen, Solís, and Katada 2007; Pempel 2006). Yet while much has been made of the strategic and diplomatic salience of the agreements, it is not clear whether PTAs in Asia Pacific have an economic rationale. In a debate conducted in several prominent journals, some observers dismiss this possibility outright and posit that these PTAs are primarily a political phenomenon (Dent 2003; Munakata 2001; Ogita 2003). Others note that the economic benefits of trade agreements are minimal if they exclude the most competitive exports of the partners 
(Ravenhill 2006, 2010). Japanese and South Korean PTAs, for example, go to great lengths to restrict agricultural imports, set small quotas, or leave agricultural market access for "renegotiation" at a future date. AsiaPacific PTAs could be merely a political fad, an imitation of developments elsewhere, or a vaguely defined political strategy to foster closer relations by diplomatic means.

In this article I challenge this interpretation. Taking the cases of Japan's and South Korea's PTAs with their partner countries in the Association of Southeast Asian Nations (ASEAN), I argue that these agreements have a clear economic rationale. The primary economic motivation, I submit, is that they benefit firms in industries with economies of scale and differentiated products. These PTAs are therefore not fundamentally different from agreements in other regions of the world, the particularity of the Japanese or South Korean policymaking processes notwithstanding.

In this article, I first develop three specific predictions for how PTAs based on such an economic argument should evolve. I then present evidence for the "demand" side based on a case study of the Japan-Malaysia Economic Partnership Agreement (EPA) and lobbying prior to and during the negotiations. Subsequently, I test the "supply side" predictions on a dataset of tariff elimination by Japan and South Korea and their ASEAN partner countries Indonesia, Malaysia, the Philippines, Thailand, and Vietnam. The evidence shows that intra-industry trade, in goods differentiated according either to consumer taste or to the capital-intensity of production, receives greater tariff preferences compared to what non-PTA countries enjoy. Conversely, imports to Japan or South Korea from partners that are based on comparative advantage-often, but not exclusively, agricultural products-are much more likely to be excluded.

In the next section I review the recent evolution of trade agreements in the Asia-Pacific region. I then discuss whether "generic" explanations can account for these developments, and find them wanting. Nonetheless, the counterargument of a purely political interpretation of AsiaPacific PTAs does not rest on stronger ground. In the third section I develop the political economy argument, and in the fourth I present the qualitative and quantitative evidence, followed by conclusions and implications of the findings of this research in the final section.

\section{Preferential Trade Agreements in Asia Pacific}

Preferential trade agreements in Asia Pacific are a recent phenomenon. For decades after (re-)gaining independence, whether after decol- 
onization or occupation during World War II, most countries in the region conducted their trade on a nondiscriminatory most-favorednation (MFN) basis. Developing countries that were also members of the General Agreement on Tariffs and Trade (GATT) (and later the World Trade Organization [WTO]) enjoyed preferential market access to the United States, European Community/European Union, Japan, Australia, Canada, and New Zealand, permitted during the 1970s thanks to a GATT waiver and later under the "Enabling Clause" agreed on during the Tokyo Round (Finlayson and Zacher 1981). These market access benefits, however, had and still have the disadvantage that they are discretionary: developed countries offer them unilaterally, and often remove them either when a developing country becomes a successful exporter or otherwise incurs the political disfavor of the granting country (Mason 2004).

Efforts to reduce trade barriers regionally began in the late 1980s with the Asia-Pacific Economic Cooperation (APEC) process, the progeny of Japanese and Australian proposals for regional integration. The Bogor Declaration set up an ambitious goal of free trade in the region by 2010 (2020 for developing countries), but subsequent initiatives were based on "individual action plans" and "early voluntary sector liberalization." Much was made at the time of the divergence between "Asian" preferences for nonbinding agreements and "Western" demands for legal treaties (Gallant and Stubbs 1997). With hindsight, however, it appears obvious that the idea of "open regionalism" (Bergsten 1997), or nondiscriminatory regional trade liberalization, would have granted non-APEC economies a free ride and was thus unlikely to succeed.

Given that APEC foundered without actually reducing trade barriers, it caught many observers by surprise that the three biggest exporters in East Asia-China, Japan, and South Korea-all suddenly began to pursue fully reciprocal trade liberalization through preferential agreements. While the labels vary, trade agreements negotiated in Asia Pacific since the turn of the millennium are in the vast majority free trade agreements (FTAs) (i.e., they reciprocally reduce trade barriers below MFN tariffs among the members only, while all members retain their own MFN tariffs vis-à-vis the rest of the world). ${ }^{1}$ If at least one of the members is a developed country and a WTO member, they fall under GATT Article 24 (and GATT Art. V if also covering services), or the "Enabling Clause" if only developing countries are involved. ${ }^{2}$ In this article, they are simply referred to as preferential trade agreements (PTAs) in line with most of the literature in economics and political science, although the countries in question use different official designations. 
East Asia is now the site of the most ongoing PTA negotiations, and has a comparable number of PTAs in force as Europe and the Americas (WTO 2011, 59) despite having started several decades later than these regions. This obviously called for an explanation, especially in light of earlier scholarship that tried to explain why formal PTAs were absent in Asia Pacific (Aggarwal 1994; Grieco 1997; Higgott, Leaver, and Ravenhill 1993; Kahler 1994). The first candidates for such an explanation are frameworks that do not define scope conditions, whether historical or regional.

\section{Generic Explanations of PTA Formation}

Past research has identified a number of "generic" causes of PTA formation that might suffice in explaining Asian regionalism. Among the most prominent is the link between regime type and PTAs. Mansfield, Milner, and Rosendorff (2002) show that democracies are twice as likely on average to conclude PTAs, and four times as likely to do so when the partner is a democratic country as well. The recent wave of PTAs is therefore a direct consequence of the spread of democracy. Indeed, as developing countries have democratized, they have also adopted more liberal trade policies (Milner and Kubota 2005). Other studies have found that allies are more likely to negotiate PTAs because they can internalize the gains from economic exchange (Gowa and Mansfield 1993; Mansfield and Bronson 1997; Mansfield and Reinhardt 2003). Even more general are explanations that emphasize the benefits of PTAs for any country dyad regardless of regime type or political relationships. Mansfield and Reinhardt (2008) suggest that an important benefit of PTAs is that they reduce the volatility of bilateral trade. They also serve as an insurance policy if multilateral efforts are stalled (Mansfield and Reinhardt 2003).

How do these approaches fare in explaining the surge in PTA formation in Asia Pacific? Not very well. Only a few countries have become democracies during the last decades (notably Indonesia, the Philippines, and Taiwan), but this did not coincide with their move toward PTAs. Other countries that remain mostly or fully authoritarian are much more active PTA seekers (Singapore, Vietnam, China). Neither are military alliances a good predictor, since no new arrangements have been created lately -if anything, the causal direction is reversed and PTAs serve as substitutes for formal defense pacts (Capling 2008).

Explanations focusing on the benefits of PTAs such as volatility reduction can only explain a time- and space-bound proliferation if 
volatility of trade has suddenly increased and triggered a reaction, or if the underlying sensitivity to such volatility has suddenly grown. There is no evidence of this in Asia Pacific either. It is possible, however, that the glacial pace of the current WTO round has motivated the formation of PTAs in Asia. This explanation is likely to be important, but is hard to test because the counterfactual is not realized. Still, it provides a partial explanation for why Asian trade was particularly at risk, should WTO negotiations fail, since Asian countries had no PTAs to ensure that markets would remain open to their exports. However, it offers little insight into the considerable variation among Asian countries, and is unlikely to be the only factor, since many PTA projects were hatched prior to initiation of the Doha Development Round and before it reached an obvious impasse.

We are left with accounts that recognize that something must have changed for an avalanche of PTAs to suddenly break loose. A likely explanation is that PTAs have become endogenous. Because preferential trade agreements are discriminatory by definition, they are likely to trigger reactions. This argument comes in different versions, variously emphasizing trade diversion (Baldwin 1996), investment discrimination (Manger 2009), or loss of market share (Baccini and Dür 2012). While there is scant evidence for the original "domino theory" because few agreements have been found to be substantially trade distorting, the latter versions find corroboration in econometric studies (Baccini and Dür forthcoming, 2012). Importantly, if PTA formation is interdependent, then it can help explain regional dynamics, including the exponential growth of PTAs in Asia. ${ }^{3}$ Concurrently, countries in East Asia may well be seeking to reassure investors, attract more FDI, and boost trade, and use PTAs as a "commitment device" that lends credibility to trade liberalization efforts (Hicks and Kim 2012).

Crucial for such explanations, however, is that they presuppose an economic explanation. Discrimination through PTAs matters when economic interests are at stake. Trade and investment links must be enhanced or protected through PTAs. Economic arguments for PTA formation usually rely on models of intra-industry trade (i.e., trade in similar goods) and economies of scale. Baier and Bergstrand's (2004) much-cited paper argues that in the long run, welfare considerations drive trade policy. PTAs will be most beneficial for relatively large economies where firms can produce and export many varieties of goods. They find considerable econometric evidence that this explains most PTAs until at least the late 1990s. Chase (2003) and 
Milner (1997) make a similar case based on a political economy argument: firms that can achieve greater economies of scale will benefit from PTAs and therefore offer political support for their formation. Yet these interpretations, some observers allege, do not apply to Asia Pacific.

\section{The Skeptics: PTAs as a Political Phenomenon}

As we have seen, although more recent system-level studies (see Mansfield and Reinhardt 2003, 2008; Mansfield and Milner 2010) include Asia-Pacific PTAs in their data, this does not automatically imply that their arguments travel well. Asia PTAs could still be statistical outliers. Potentially more important, however, is that economic arguments draw on examples of PTAs outside the region, mostly the North American Free Trade Agreement (NAFTA) (Chase 2003; Milner 1997) or European integration (Baldwin 1996; Baldwin, Forslid, and Haaland 1996). Do these apply to Asia at all? A number of observers disagree. Instead, they have located the driving force behind PTAs in Asia among governments (Dent 2003, 13-14; Krauss 2003; Ogita 2002). Industry interests do not feature at all in this account, although much is made of the often protectionist positions of the developed countries on agriculture. The strongest (and clearest) skeptical position is presented by Ravenhill (2006, 2010), who calls East Asian regionalism a "political domino effect," rarely economically meaningful, and sometimes just "banal."

These arguments rest on four claims: First, PTAs in East Asia are initiated and driven by governments, not private sector interests, who either are uninterested or ignorant bystanders or simply lack influence. Second, the structure of the agreements suggests that they do not reflect actual trade interests, since those sectors where the gains from trade are potentially greatest are usually excluded. Third, they are not actually used by firms and hence are unlikely to generate much trade. Finally, because the trade partners are either small or relatively unimportant for the various countries' total exports, the economic benefits are likely to be minimal.

Let us take up these arguments in reverse order. That the trade partners are relatively unimportant for each other's trade is only partially correct. For the "ASEAN-6"-Indonesia, Malaysia, the Philippines, Singapore, Thailand, and Vietnam-for example, UN COMTRADE data show that Japan and South Korea have been among their top-three trading partners since the mid- to late 1990s. The reverse is clearly not true-Japan's most important trading partners remain the 
United States, China, and the European Union-but such asymmetries are evident in other regions as well: Germany is vastly more important as an export market for the Netherlands than vice versa.

The relatively limited use of PTAs by exporting firms appears merely a result of the recent entry into force and still ongoing implementation of PTAs. Takahashi and Urata (2010) find, based on a 2008 survey, that 32.9 percent of exporters to Mexico used the JapanMexico PTA (in force since April 2005), while only 12.2 percent used the benefits available through the Japan-Malaysia PTA (in force since July 2006). But notably, in some industries, utilization rates are much higher, exceeding 50 percent in transportation machinery in the case of Mexico and 26 percent in the case of Malaysia, even though the latter agreement had been in force for only eighteen months when the survey was conducted. While most firms noted that trade volumes were low and certificates of origin difficult to obtain, very few (6 percent in the case of the Japan-Mexico PTA and 9 percent in the case of the Japan-Malaysia PTA) found that the tariff preferences were too small. In other words, tariff benefits matter, but it is costly for firms to avail themselves of them. Consequently, the authors also find that larger firms in particularly capital-intensive industries make much greater use of PTA benefits. However, utilization rates are growing rapidly-reflecting either learning about the benefits available or a rational decision to obtain certificates of origin only when firms achieve sufficient economies of scale. Hence the utilization rate within the first two years of ratification of a PTA tells us little about whether a PTA has been concluded for economic reasons. Moreover, there is evidence that the average cost to firms to use PTA benefits is between just 3 and 5 percent (Hayakawa 2011). Japanese and South Korean PTAs are likely to be at the lower end of this estimate, since their rules of origin-the most expensive "red tape"-are much simpler than those in PTAs signed by the United States or the European Union. Finally, more recent work on the utilization rates of the ASEAN-South Korea PTAs has disaggregated the data and found very high rates of 70-90 percent in cases such as Indonesian, Thai, and Vietnamese exports to South Korea (Hayakawa, Kim, and Lee 2013). Clearly, more and more firms are availing themselves of the tariff benefits provided by these PTAs.

Let us therefore turn to the strongest claims: that PTAs are government driven, and that their design (in other words, the liberalization they entail) has little economic relevance. To counter this argument, we need to revisit political economy explanations of PTA formation. 


\section{The Economic Logic of Asian PTAs}

According to textbook economics, the gains from trade liberalization will be greatest when countries can specialize according to their comparative advantage. But such liberalization is bound to be difficult in PTAs. By definition, specialization entails considerable adjustment costs as inefficient producers shut down and capital and labor are reallocated. In general, such adjustment costs are highly concentrated, but in the case of a PTA, the offsetting gains will be spread thinly across consumers and small compared to a multilateral agreement with many partners. This means that PTA ratification is going to be politically challenging unless the countries have similar factor endowments, or inefficient sectors can remain protected. In either case, the gains from trade will be limited.

This argument can be applied immediately to PTAs in Asia Pacific, and in particular Japan's PTAs. As Pekkanen, Solís, and Katada (2007) have argued, PTAs are attractive for Japan precisely because inefficient sectors can be excluded-Japan trades off "gains for control" of the negotiations. But the authors do not imply that these agreements are without an economic rationale. The economics behind "traditional" gains from trade are neoclassical: firms have constant returns to the scale of their production, competition is perfect, and countries exchange completely different goods. Political economy theories of the last two decades, however, have recognized that these are insufficient to explain PTA formation. Instead, the economic interests driving PTA formation depend on industries characterized by economies of scale.

As Milner (1997) and Chase (2003) have shown for the case of NAFTA, firms can gain economies of scale by expanding in a regional market. Economies of scale are achieved when manufacturing costs per unit of good decline as the number of units produced increases. This is typically the case in capital-intensive industries with large production plants that require significant investment-take the automobile and steel industry as example. In other industries, firms can also achieve economies of scale in back-office operations (such as in retail banking) or in research and development or design (such as, for example, in global fashion brands). But there is a crucial difference between these industries and capital-intensive manufacturing: in the latter case, firms achieve economies of scale at the plant level. This means that they can increase their returns when they can produce more units for a given investment in a production site. One natural avenue is to increase exports from the plant. Crucial for the 
economic benefits of PTAs for these firms is that they can keep them exclusive to the PTA partners-in other words, through PTAs that are both liberalizing regionally while retaining some external protection (Chase 2003, 143-145).

In the negotiation of a PTA, governments will therefore rely on the support of firms in industries characterized by economies of scale. In general, when products are differentiated by "tastes" (e.g., different brands of vehicles), firms can specialize with relatively lower adjustment cost: here, specialization requires a minor adaptation of the product, but not of the production plant, and no major reallocation of resources. ${ }^{4}$ This makes reciprocal market-opening feasible, because governments can exchange liberalization offers of different industries: " $[I] n$ industries with differentiated products, this swapping of markets across countries may be possible at low political cost" (Milner 1997, 91). Such trade is often referred to as "horizontal intra-industry trade" (HIIT).

Although useful, this model fits best when explaining PTA formation between countries of high and similar levels of economic development-the Canada-US PTA and in particular (West) European integration. In Asia Pacific, a different kind of PTA is more common: large, developed economies, in particular Japan and (WTO classification as developing notwithstanding) South Korea, have partnered up with smaller, developing countries. Given that the factor endowments of these countries differ considerably and the bargaining situation is highly asymmetrical, these PTAs should indeed, as observed by Ravenhill (2010), result in very little liberalization. But this overlooks that gains from intra-industry trade are possible because firms can produce at more efficient scales in an enlarged market. In Manger (2012), I take up the puzzle that more recent PTAs are often North-South agreements between countries of unequal size, and submit that vertically specialized intra-industry trade (i.e., where goods are primarily differentiated by unit value and "quality" differences) can be equally important. These models apply to Japan's and South Korea's PTAs in Asia Pacific as well, but instead of firms in each country differentiating their products by "taste" or "variety," many are specializing vertically. In the models developed by Milner and Chase, firms either export from their home country if they can achieve economies of scale, or they replicate their production abroad if they require an "additional" plant to serve that market. By contrast, vertical specialization means that firms differentiate their products by "unit value": some firms produce goods with a 
higher per unit value, others with a lower per unit value. This means that firms can serve different market segments in the same industry.

In the case of a PTA between a developed and a developing country, such as Japan's and South Korea's PTAs with their regional partners, different "market segments" correspond to two characteristics of these economies. First, in developed countries, relatively more people can afford high-priced goods, while in developing economies, the market for low-priced goods is relatively bigger. Second, the production of goods with a higher unit value tends to be more capital intensive. This makes such production in richer countries more profitable than in relatively capital-poor developing countries. In other words, while the technology creates economies of scale, the factor endowment of the country induces the product differentiation.

The result is that countries trade goods in the same industry, but that such trade is differentiated by the unit value of the goods. This is referred to as vertical intra-industry trade (VIIT) (Abd-el-Rahman 1991; Greenaway, Hine, and Milner 1994; Krugman 1981). Such trade, I submit, provides an economic rationale for many (although clearly not all) PTAs in Asia Pacific, and is the principal economic driving force behind Japanese and South Korean PTAs with regional partners. Vertical IIT is not necessarily as easy to liberalize as horizontal IIT, but it is substantively more important in a region like Asia with pronounced differences in per capita incomes, levels of wages, and fixed capital per worker.

A different way to conceptualize intra-industry trade in East Asia is to focus on production networks and multistage processing. Such data are difficult to obtain (for one of the most sophisticated attempts, see Athukorala 2010), and detailed analysis of such networks requires firm-specific data collection (see, e.g., Alfaro and Charlton 2009; Hiratsuka 2011). Production networks developed in East Asia long before any preferential trade agreements were discussed (Borrus, Ernst, and Haggard 2000), and influence PTA design today through investment rules and other regulations (Kim 2014). Network trade is related but conceptually different from vertical intra-industry trade. In a production network, a good is processed in multiple stages in different locations, with inputs procured from all across the region. VIIT, on the other hand, is a bilateral phenomenon, of which some part may be the result of an existing production network.

VIIT is often the result of foreign direct investment (FDI) in a host country with a lower wage level than in the home location of a multinational firm. This process of "outsourcing" may occur for parts 
as well as for finished goods. However, FDI is neither necessary nor sufficient for VIIT: the "matching" producer of low-unit-value exports in the partner country could originate from that country's firms, while all FDI could serve the market in the partner country without any contribution to exports. Still, a more pronounced role of FDI is likely to increase political support for the formation of a PTA, as it raises the stakes for multinational firms.

Since the Asian financial crisis in 1997-1998, vertical intraindustry trade has become considerably more important in the trade between Japan and South Korea on the one side and their most important Southeast Asian partners on the other. While it would be desirable to directly test the association between an increase in vertical intra-industry trade and PTA formation for East Asian countries in an econometric model, the necessary data are not available for a sufficient number of countries in Asia. ${ }^{5}$ Visual inspection, however, suggests a correlation. Figure 1 shows the growth of trade between Japan and South Korea with Thailand, Malaysia, and Vietnam between 1998 and 2006. In all six cases, vertical intra-industry trade grew in importance, both absolutely because trade increased, and relatively because VIIT became more important in the trade relationship. In some cases (South Korea-Thailand and Japan-Vietnam) almost all the expansion of bilateral trade can be attributed to the growth of VIIT. In the graphs, the vertical line shows the year in which the preferential trade agreement between the two countries was signed. In all cases, this followed an extended period of increase in VIIT.

When trade is liberalized between two countries, firms can take advantage of such vertical specialization by producing each good where it is most efficient to do so and where the greatest demand exists, and by trading the goods back and forth. Models of vertically specialized firms (Feenstra 2004, 386) predict that the demand for less-skilled labor increases in the country with lower wages (in this case the ASEAN countries) and the demand for high-skilled labor in the country with high wages (i.e., in Japan and South Korea). What's more, recent product-level evidence shows that FDI by Japanese upstream firms (i.e., suppliers to manufacturing firms) is followed by more exports of intermediate goods from Japan (Nishitateno 2013). Both firms and workers in each country therefore have an incentive to lobby for and to support trade liberalization.

With multilateral liberalization efforts stalled at this point, preferential trade agreements are the most feasible alternative. Yet PTAs 


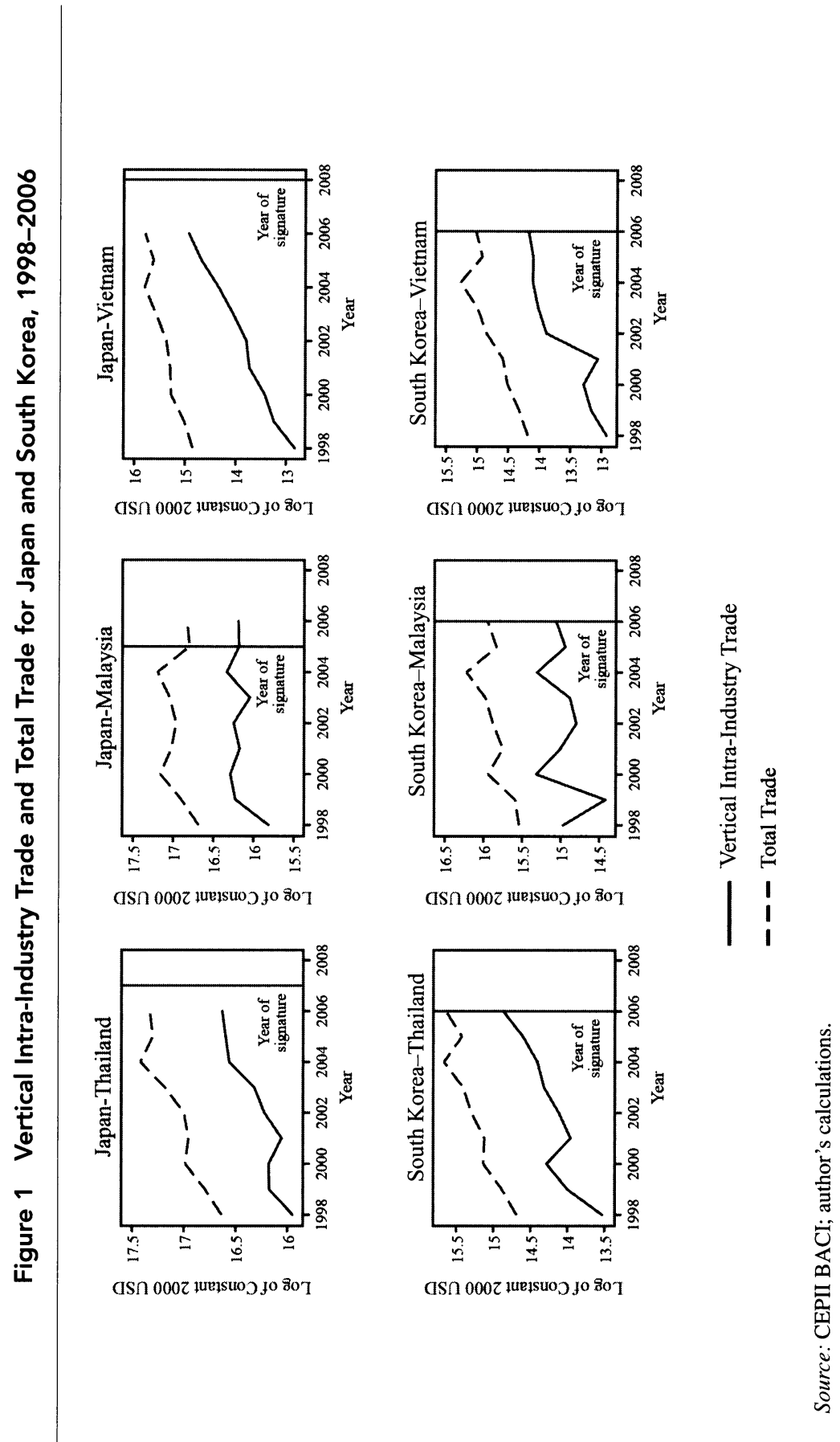


also have the advantage that tariff reductions on intra-industry trade can be tailored to the trade between the two countries without requiring liberalization of primarily endowment-based inter-industry. By comparison, a multilateral agreement is likely to link such issues (Davis 2004) and result in an economically superior, but politically much more demanding, outcome.

Why would governments support such liberalization? According to the canonical political economy model (Grossman and Helpman 1994), if we assume that politicians are primarily interested in reelection, they will care about consumer surplus, favors from special interests, and tariff revenue. The latter is largely irrelevant except for least-developed countries. Accordingly, if a policy avoids reducing consumer surplus, but offers some benefits to particular interests, politicians will pursue it. PTAs are an instance of such a policy. Industries with significant economies of scale, export orientation, and investment in the partner country therefore form a special interest group whose demands can be met by decisionmakers with relative ease. ${ }^{6}$

In sum, if this political economy explanation is correct, then three predictions would have to be met:

1. Firms that engage in intra-industry trade should be the most vocal (or perhaps the only) private sector supporters of Japanese PTAs with regional partners;

2. Tariff reductions should reflect this trade: greater preference margins should be created by PTAs for such differentiated goods; and

3. Intra-industry goods should be less likely to be excluded from liberalization than other goods.

In the next section, I provide evidence for such a trade-off in the case of the Japan-Malaysia PTA.

\section{Testing the Argument}

In this section, I first provide qualitative evidence for the lobbying demands of firms, many of which predate negotiations. I then proceed to a statistical test of the predictions regarding tariffs and exclusions in the subsequent section. I specifically focus on the JapanMalaysia free trade agreement, as the low utilization rate cited by Takahashi and Urata (2010) and the relatively lesser importance of VIIT in the bilateral trade relationship compared to Thailand and 
Vietnam as shown in Figure 1 make it a least-likely case that PTA formation was based on economic interests.

Qualitative Evidence: The Japan-Malaysia PTA

Japan's PTA with Malaysia (officially the Japan-Malaysia Economic Partnership Agreement) was Japan's third agreement after the deals with Singapore and Mexico. Negotiations began in December 2003 and were concluded in early 2005 . Following ratification, the agreement entered into force in July 2006. In the year prior to the beginning of negotiations, Japan was the third-most important export market for Malaysia, but Malaysia was only the tenth-largest export market for Japan. This suggests that gains from trade would not be overwhelmingly large in relation to the economies of either party.

The Japan-Malaysia PTA was among the earliest PTAs in the region to be signed and implemented, but could still be seen as a reaction to other ASEAN countries' policies: Malaysia was competing with its ASEAN neighbors for foreign direct investment in the auto industry. Thailand in particular had become an attractive location following the rapid depreciation of the baht during and after the Asian financial crisis. The Malaysian government had been critical of initiatives by ASEAN members to individually seek trade agreements with partners outside the region (Athukorala 2005, 32), but had also failed to implement ASEAN Free Trade Area commitments to liberalize trade in cars and parts (Kiyota 2006, 218). Malaysian government sources expressed concern that investment in the electronics industry threatened to decline, as many Japanese firms chose projects in mainland China instead. ${ }^{7}$ In 2002, the year prior to the start of negotiations, Malaysia had received 109 investment applications from Japan, mostly by small- and medium-sized companies that sought to manufacture precision parts, tools, and dies, a lower figure than in previous years. ${ }^{8}$

Most Japanese capital flowed into the consumer electronics and car parts industries. By comparison, the Malaysian vehicle market remained heavily protected and dominated by two local producers (Proton and Perodua). Given this situation, we would expect Japanese firms with investment in Malaysia to lobby for tariff reductions, but these would be differentiated to reflect the unit price of a good: there would be demands for faster liberalization of high-unit-value goods. Conversely, we would see attempts by Japan to exclude export goods from Malaysia from the negotiations that reflected starkly differing comparative advantage - concretely, agricultural products. 
The principal supporters of an agreement in Japan were the automotive, electronics, and steel firms, all capital intensive in their production. In a trade newspaper, Japanese executives were cited noting that a PTA would eliminate duties on inputs for Japanese firms in Malaysia. ${ }^{9}$ Minister for Economy, Trade, and Industry (METI) Nakagawa focused on striking a deal that reduced tariffs on steel products, car parts, and vehicles. With regard to trade barriers in the automotive and steel industries, private sector demands closely reflected the specific problems of firms. In a paper published prior to the start of negotiations with Malaysia, the Japan Business Council for Trade and Investment Facilitation (bōeki tōshi enkatsuka bijinesu kyōgikai) (2003), an umbrella group of 130 manufacturing industry associations, listed Malaysian vehicle parts tariffs in considerable detail, and requested a "reduction of tariffs to a reasonable level" (tekisei suijun he no kanzeiritsu no hikisage). Of the nineteen pages in the section on Malaysia in the paper, twelve address a variety of tariff and nontariff barriers, often with reference to ASEAN Free Trade Area rules. While there was no explicit demand for a PTA, it is clear that the elimination of trade barriers was of considerable concern to this industry association before the negotiations. Moreover, in the autumn of 2003, while a joint study group still evaluated the benefits of a Japan-Malaysia PTA, Japan's peak industry association Keidanren issued an "urgent call for the opening of negotiations with Malaysia" (Yoshimatsu 2005, 263). While tariff reductions would be gradual, tariffs on luxury cars would be dropped five years earlier than those on smaller vehicles, because they did not compete with Malaysianproduced cars. ${ }^{10}$

These demands were mirrored on the Malaysian side. The Malaysian government consulted closely with the leadership team of Proton, the larger of the two Malaysian auto producers, to determine the possible consequences of liberalization. ${ }^{11}$ Proton insisted on the longest protection for vehicles with less engine displacement, but conceded a quicker tariff-free market entry for those over $2,000 \mathrm{cc}$. Nonetheless, these tariff-phasing patterns for cars were heavily influenced by the facts that Japanese exports competed with technologically inferior local products that had been developed as part of an import-substitution strategy, and that Malaysia did not export any finished vehicles to Japan.

More pertinent examples of vertical differentiation of products in PTAs arose in the household appliance industry, where nearly all trade was two-way and differentiated by unit value, and in chemicals and steel products, where Japan-based firms supplied producers in 
Malaysia and vice versa. ${ }^{12}$ In the electronics and appliances industry, vertical differentiation was far more advanced prior to the negotiations, since Malaysia had become a hub for Japanese producers who did not have local competitors. Virtually all electronics manufacturers in Malaysia were 100 percent Japanese owned but employed mostly local Malay staff. Exports of electronics and electronic appliances made up close to 31 percent of Malaysian exports to Japan in 2004 and a comparable percentage in the reverse direction. ${ }^{13}$ Accordingly, firms in both countries supported the deal.

More contentious was the liberalization of steel products, since some local steelmakers supplied inputs for the Malaysian domestic car industry, and opposed any market opening. The deal therefore provided for phased tariff elimination, with duties remaining in place for fifteen years for those specific tariff categories dominated by products made by and for local Malaysian-owned firms. Meanwhile, special duty-exempt categories were created for steel as an input for products that were then re-exported. ${ }^{14}$

Following the pattern of exclusions or limited market opening for primary products, Japan eliminated tariffs for other wood products, but not the most competitive exports-plywood and derived products were either subject to a seven-year phase-in period or not offered any liberalization-despite the fact that the Malaysian government had made this a central demand. ${ }^{15}$

In sum, there is much evidence from demands and the negotiations themselves that capital-intensive industries supported tariff reductions. Of course, the problem with news reports and "oral history" is that while they may suggest a causal relationship, as evidence they are likely to be biased-or more precisely, we cannot know just how biased. This applies to pronouncements from government officials and private sector representatives alike. Unsurprisingly, then, that authors who draw on interviews with government officials in METI or the Ministry of Foreign Affairs or official pronouncements find that Japan's PTA policy is government driven (Krauss 2003; Ogita 2003), while those who interview industry representatives take a different view (Manger 2005, 2009; Solís 2003). Even less surprising is that when former METI officials themselves analyze the reasons for PTAs (Munakata 2001; Sekizawa 2008), they will find it to be a rational policy initiated by enlightened, dispassionate civil servants.

Moreover, given that the Japan-Malaysia PTA could be driven by a host of other factors, we could be accused of cherry-picking to favor our argument. Qualitative evidence will therefore only take us part of the way, although it suggests that the pattern of lobbying and 
the specific demands match our first prediction. To corroborate the claims in this article, a statistical analysis is necessary.

\section{Quantitative Evidence}

In the previous section, I offered evidence of demands for specific liberalization to be undertaken by Japan's PTA partners, and of the well-known protectionist forces in Japan. In line with the argument advanced here, if economic support were in fact important for the conclusion of PTAs in the region, we would see these demands reflected in the supply of PTAs. More specifically, the pattern of tariff reductions should correspond to these demands. Sectors that would face considerable adjustment costs would retain protection. This should be particularly prominent when trade is based on comparative advantage. By contrast, the trade that reflects the interests of multinational firms and suppliers, the most vocal supporters of Japan's and South Korea's PTAs, should obtain the most liberalization. In this section, I present statistical evidence that the tariff reductions by Japan, South Korea, and their ASEAN PTA partners match this prediction. ${ }^{16}$ I also show that the more different the comparative advantage of the two countries, the more likely a particular trade good is wholly excluded from liberalization by Japan and South Korea. The analysis covers ten PTAs in total, since the Japanese PTAs were negotiated prior to the Japan-ASEAN PTA and have separate schedules, and because the South Korea-ASEAN PTA, while ratified jointly, in reality contains separately negotiated bilateral tariff schedules for South Korea and each ASEAN partner.

Operationalization and data. I use two dependent variables in this analysis. The first is the PreferenceMargin, or the difference between the tariff (possibly equal to zero) that Japan's or South Korea's PTA partner offers in a particular product category after the full implementation period of the PTA, and the MFN tariff applied by the partner country at the time of signing of the PTA. This variable reaches its maximum when the preferential margin is greatest, in other words, when the Japanese or South Korean side has obtained significant concessions compared to non-PTA partners. It reaches its minimum in two possible cases: first, if there is no MFN tariff on the good to begin with, and the PTA merely locks in existing zero tariffs; or second, if there is a high tariff, but Japanese or South Korean exporters gained no further market access. In other words, the preferential margin should be at its minimum if PTAs have no economic benefits for Japanese or South Korean exporters. I focus on applied MFN rates 
because bound rates often exceed them greatly. ${ }^{17}$ This model is called the liberalization model and applies to exports from Japan and South Korea to their ASEAN partners.

The second dependent variable is the whether a particular good has been Excluded from tariff liberalization completely by Japan or South Korea, in other words, where Japan or South Korea only offers the existing MFN tariff to their PTA partners, retains a tariff-rate quota, ${ }^{18}$ or leaves the tariff for renegotiation at some future date. This model is called the exclusion model and applies to exports from ASEAN countries to Japan and South Korea.

PreferenceMargin and Excluded simply measure the preferential tariff margin obtained or, respectively, the likelihood of exclusion from liberalization for a specific good at the level of an individual six-digit harmonized system (HS6) tariff.

The key independent variable in this analysis is a dummy for the trade type: whether a good is part of vertical (VIIT) or horizontal intra-industry trade (HIIT), or whether it is due to comparative advantage, in which case it is classified as one-way trade (OWT). For the definition of the trade types, I follow Fontagné and Freudenberg (1997) and Fontagné, Freudenberg, and Gaulier (2005). ${ }^{19}$ The calculation is based on the following algorithm: I first check if there is trade in both directions between two partners in a particular product category, defined as a six-digit tariff line in the 1992 Harmonized System of the World Customs Organization, the finest level of disaggregation that is undertaken systematically in Asia-Pacific PTAs. ${ }^{20} \mathrm{I}$ record the flow as one-way trade if the value of exports in one direction is less than 10 percent of the value of the exports in the other direction. The intuition is that countries sometimes trade small amounts of goods that are the extreme opposite of their comparative advantage, but that these exports should not be considered a structural characteristic of their bilateral trade relationship. To take a concrete example, Australia exports some cars to Japan, while Japan exports some beef in return. ${ }^{21}$

The remaining trade is (bidirectional) intra-industry trade. I further separate this trade into its vertical and horizontal variety, reasoning that in particular vertical intra-industry trade should generate sufficient political support for liberalization because product differentiation is already evident, so firms do not need to change their products and can still export the same goods. An example of such vertical specialization is found in the trade in cars between Japan and Germany, which is balanced in total value, but differs in unit value: Japan mostly exports smaller vehicles to the other country, while Germany mostly exports luxury vehicles. 
I use Fontagné and Freudenberg's (1997) threshold of 25 percent difference in the value of the units traded. If goods in the same tariff category but with unit values differing by more than 25 percent are traded, then these exports are classified as vertical intra-industry trade. If the unit value difference is 25 percent or less, then the exports are counted as horizontal intra-industry trade (HIIT).

In the first two models, I test whether exports in the different trade types are a predictor of a greater preference margin. In Model 1, I use dummy variables called, respectively, HIIT and VIIT, and use OWT as the omitted base category. This approach has the advantage of clearly capturing that the trade types are mutually exclusive, and makes the parameters in the Tobit model easy to interpret. In Model 2, I replace this with the (logged) value of HIIT and VIIT trade, called HIITlevel and VIITlevel. In the second set of models, I test whether different trade types are predictors of exclusion from PTA preferences. Again, in Model 3 I use dummy variables called, respectively, HIIT and VIIT, and use OWT as the omitted base category, and in Model 2, the (logged) value of HIIT and VIIT trade.

Following Achen (2002) and Schrodt (2010), I "test up," drop control variables that are not significant even at the 10 percent level in any specification unless there are very strong theoretical reasons to include them, and focus on a minimal political economy model.

I include a control variable at the industry level, matching the International Standard Industrial Classification (ISIC) four-digit industry classification to HS6 tables with the concordance table available from the Centre d'Etudes Prospectives et d'Informations Internationales (CEPII): ${ }^{22}$ ImportCompetition, calculated as imports of goods produced by this industry (from any country source) divided by the domestic consumption of such goods. Endogenous trade models, in particular the specific factors model, consistently predict greater protection for import-competing industries (Nelson 1988). Data for this variable are from the UNIDO Supply and Demand Statistics database. This variable imposes the principal constraint on the sample because some countries do not report data on sectors consistently and for all years, but the cross section does not offer enough information for imputation. The variable ranges from 0 (all consumed goods in the category are imported) to 1 (all consumed goods are produced at home). Smaller values of ImportCompetition indicate that an industry is relatively less competitive than its counterpart in the other country. Note that small values do not imply that an interest group is automatically weak, in fact much to the contrary: "sunset industries" like textiles or footwear continue to obtain pro- 
tection even when their contribution to employment and industrial output in a country is negligible. Conversely, industries that are highly competitive compared to exports are less inclined to seek protection, so that the expected coefficient is negative in the liberalization model and positive in the exclusion model.

I furthermore control for the bilateral Exports (in log of constant 2005 USD) in the tariff category, with data from the CEPII database, reasoning that large exports are more likely to trigger a "rearguard action" of affected industries in the importing country, so that the expected sign of the coefficient is negative in the liberalization model and positive in the exclusion model. Finally, I include a measure of (the log of) bilateral flows of FDI, obtained from the Exim Bank of Korea and the Ministry of Finance of Japan. Since intra-industry trade is often driven by investment by multinational firms from the developed partner country, there are strong theoretical reasons to include this variable. A better measure would be the flow of FDI in each industrial category, but unfortunately the data are not comparable for Japan and South Korea: Japan reports the total FDI stock and FDI stock by industry (at the three-digit level) for each partner country but not the flow. South Korea, on the other hand, reports only FDI flows by industry (at the two-digit level) and the total FDI stock. Hence the only matching statistic is the total FDI flow in each partner country in historical dollars without any disaggregation by industry. However, the stock data suggest that $80-90$ percent of the flows are in any case manufacturing FDI, so that this is a reasonable approximation.

For the control variables, I include five-year averages for the values at $t-5$ to $t-1$, as I expect industries to lobby for or against protection based on longer-term developments of relative competitiveness rather than annually fluctuating values, except for the FDI flow variable where I can only use the measure at $t-1$ due to data limitations. Merely taking the most recent value does not substantively change the results, however. ${ }^{23}$ In an appendix ${ }^{24}$ I provide the results for alternative specifications and controls, in particular including a bilateral measure of import competition, but the substantive conclusions are not affected by these changes. Table 1 shows a summary of the expected signs of the coefficients.

The variable PreferenceMargin never takes on negative values. It is of course theoretically possible that countries set a final tariff for a specific good after the phase-in period of a PTA that is higher than the MFN tariff, whether bound or applied at the time of treaty signature, but in practice this never occurs in the cases in question. The appro- 
Table 1 Expected Coefficient Signs

\begin{tabular}{lc}
\hline Independent Variable & Expected Sign \\
\hline Dependent variable: PreferenceMargin & + \\
VIIT or InVIITvalue & + \\
HIIT or lnHIITvalue & - \\
ImportCompetition & - \\
lnExports & + \\
lnBilateralFDIFlows & \\
Dependent variable: Excluded & - \\
VIIT or InVIITvalue & - \\
HIIT or InHITvalue & + \\
ImportCompetition & + \\
lnExports & \\
\hline
\end{tabular}

priate model is therefore a censored regression or Tobit model. ${ }^{25}$ For the binary dependent variable Excluded I estimate a logit model.

As the observations cannot be assumed to be independent within the same PTA, I cluster observations over the PTA partners-Indonesia, Malaysia, the Philippines, Thailand, or Vietnam-(i.e., the specific trade agreement) and use a bootstrap procedure to obtain correct standard errors. ${ }^{26}$ While the South Korea-ASEAN PTA is a single agreement, it has a common tariff schedule as well as individual exceptions by country, so that the same approach is warranted.

Results. Table 2 shows the results for both models. Recall that the prediction is that HIIT and VIIT should receive a greater preference margin, but be less likely to be excluded from preferential liberalization. These predictions are borne out by the results. In the first analysis, the dummies on vertical and horizontal intra-industry trade (VIIT and HIIT) are positive and significant.

To illustrate the effect of the coefficients in column (1), consider a hypothetical tariff category, change the trade in this category from inter-industry to intra-industry trade, holding the other variables at their mean. The tariff preferences obtained for VIIT would then be approximately one-fifth greater and for HIIT about one-third greater than in the inter-industry case. ${ }^{27}$ Recall that in practice VIIT is substantively vastly more important-about 25 percent of trade in the sample is VIIT, while only 4 percent is HIIT - so that a greater number of tariff lines are receiving the one-third greater preference margin. This suggests that HIIT is indeed easier to liberalize than VIIT. The marginal effects for the expected value of the dependent variable 
Table 2 Regression Results

\begin{tabular}{|c|c|c|c|c|}
\hline \multirow[b]{2}{*}{ Independent Variable } & \multicolumn{2}{|c|}{ PreferenceMargin } & \multicolumn{2}{|c|}{ Excluded } \\
\hline & (1) & (2) & (3) & (4) \\
\hline HIIT & $\begin{array}{c}2.911 * * \\
(0.713)\end{array}$ & & $\begin{array}{c}-0.782 * * \\
(0.269)\end{array}$ & \\
\hline VIIT & $\begin{array}{l}1.994 * * \\
(0.539)\end{array}$ & & $\begin{array}{c}-0.387^{*} \\
(0.151)\end{array}$ & \\
\hline InHIITvalue & & $\begin{array}{c}0.403 * * \\
(0.107)\end{array}$ & & $\begin{array}{c}-0.267 * * \\
(0.071)\end{array}$ \\
\hline InVIITvalue & & $\begin{array}{l}0.254^{*} \\
(0.114)\end{array}$ & & $\begin{array}{c}-0.158^{* *} \\
(0.033)\end{array}$ \\
\hline $\operatorname{lnExports}$ & $\begin{array}{c}-0.520^{*} \\
(0.224)\end{array}$ & $\begin{array}{c}-0.566^{*} \\
(0.235)\end{array}$ & $\begin{array}{l}0.119^{*} \\
(0.051)\end{array}$ & $\begin{array}{c}0.157 * * \\
(0.049)\end{array}$ \\
\hline ImportCompetition & $\begin{array}{c}-16.501^{* *} \\
(4.575)\end{array}$ & $\begin{array}{c}-16.693 * * \\
(4.634)\end{array}$ & $\begin{array}{c}-0.932 \\
(0.522)\end{array}$ & $\begin{array}{c}-1.085^{*} \\
(0.515)\end{array}$ \\
\hline InBilateralFDIFlows & $\begin{array}{c}0.092 \\
(1.663)\end{array}$ & $\begin{array}{c}0.088 \\
(1.663)\end{array}$ & & \\
\hline Constant & $\begin{array}{c}16.235 \\
(10.306)\end{array}$ & $\begin{array}{c}16.783 \\
(10.362)\end{array}$ & $\begin{array}{c}-4.645^{* *} \\
(0.397)\end{array}$ & $\begin{array}{c}-4.680^{* *} \\
(0.403)\end{array}$ \\
\hline Observations & 15,569 & 15,569 & 18,865 & 18,865 \\
\hline Clusters & 9 & 9 & 10 & 10 \\
\hline Log-likelihood & $-49,295.591$ & $-49,317.839$ & $-1,104.199$ & $-1,090.207$ \\
\hline
\end{tabular}

Notes: * significant at 5 percent; ** significant at 1 percent. Columns (1) and (2) are Tobit estimators; (3) and (4) logit estimators. Two-tailed tests are conducted for all estimates. Standard errors (SE) are bootstrapped by resampling from PTA clusters with 1,000 repetitions.

conditional on being uncensored are shown in Table 3. The control variables ImportCompetition and Exports have the expected sign and are statistically significant in the liberalization model. Marginal effects at the 25th, 50th, and 75th percentiles of the continuous measures of VIIT and HIIT are presented in Table 4. Both show a slight increase at upper values of the variables.

Now consider the effect of VIIT and HIIT on the likelihood that a good is excluded from liberalization by Japan or South Korea. To recall, our hypothesis is that if a good is intra-industry trade, it should be less likely to be excluded because domestic adjustment in Japan should be easier. Indeed, the results shown in column (2) suggest that this is the case. We can compare the substantive importance by dividing the probability when the respective intra-industry dummy is 0 to when it is equal to 1 , and by dividing the probability when a continuous variable is at its mean by the probability at its mean plus one standard deviation, or in the case of dummy variables when the value moves from 0 to 1 . This is often referred to as calculating the "relative risk" contribution. 
Table 3 Conditional Marginal Effects (Tobit model)

\begin{tabular}{lrrrr}
\hline & $\mathrm{dy} / \mathrm{dx}$ & $\mathrm{SE}$ & \multicolumn{2}{c}{$95 \% \mathrm{CI}$} \\
\hline HIIT & 1.217 & 0.289 & 0.652 & 1.783 \\
VIIT & 0.763 & 0.325 & 0.127 & 1.400 \\
lnExports & -0.178 & 0.100 & -0.374 & 0.017 \\
ImportCompetition & -8.571 & 1.877 & -12.250 & -4.892 \\
\hline
\end{tabular}

Table 4 Marginal Effects of Continuous Variables (Tobit model)

\begin{tabular}{lccccc}
\hline & Percentile & Marginal Effect & SE & \multicolumn{2}{c}{$95 \%$ CI } \\
\hline InVIITvalue & 25th & 7.843 & 1.996 & 3.929 & 11.757 \\
& 50th & 8.218 & 1.953 & 4.390 & 12.047 \\
& 75th & 8.659 & 1.920 & 4.896 & 12.423 \\
InHIITvalue & 25th & 8.196 & 2.384 & 3.523 & 12.869 \\
& 50th & 8.843 & 2.511 & 3.922 & 13.765 \\
& 75th & 9.607 & 2.667 & 4.379 & 14.835 \\
\hline
\end{tabular}

Compared to the baseline category of inter-industry trade, vertical intra-industry trade is only 0.68 times as likely and horizontal intra-industry trade only 0.46 times as likely to be excluded. Again, recall that vertically specialized trade is substantively much more important than horizontal intra-industry trade in most PTAs between a developed and a developing partner. The point predictions of this relative risk contribution are shown in Figure 2.

In the exclusion model, the control variable lnExports has the correct sign and is significant, but the variable ImportCompetition is not significant. This may reflect that if an industry is completely protected from imports, like (still) many agricultural producers in Japan and South Korea, there simply are no substantially important imports in the product category, so that the effect cannot be estimated with certainty. Including the InBilateralFDIFlows data as a control turns out to be statistically insignificant, which given the strong theoretical expectation is most likely due to the relatively crude measure of foreign investment. Nothing changes about the magnitude or statistical significance of the remaining coefficients, so the conclusions are unaffected.

Overall, it is unlikely that these results are chance, and improbable that they are the result of policy choices of bureaucrats with no input from industry. Hence the design of Japanese and South Korean PTAs clearly reflects economic interests. 
Figure 2 Contribution to Relative Risk of Exclusion (Model 2)

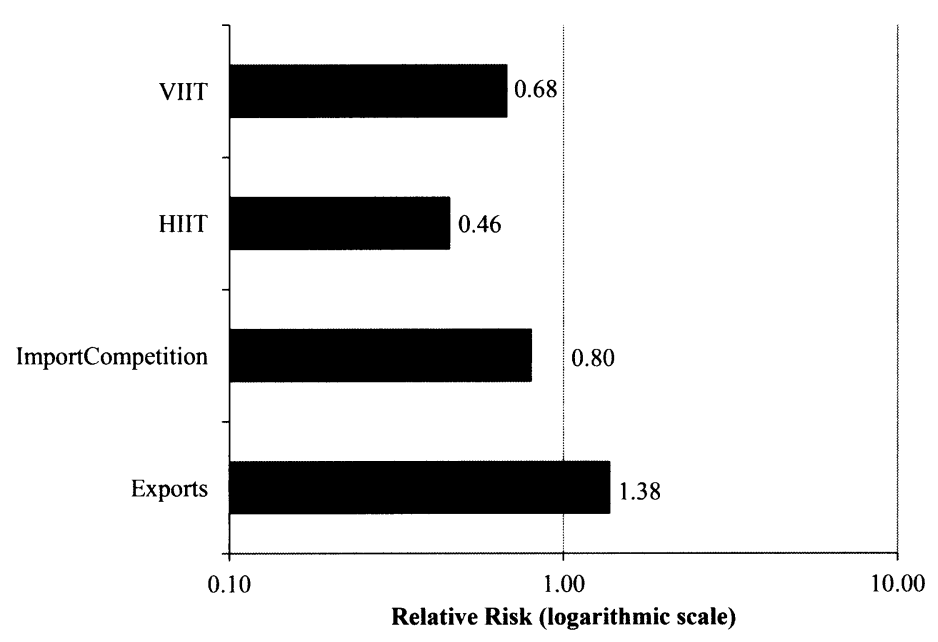

\section{Conclusion}

Japanese and South Korean PTAs with ASEAN partners, I have argued, have a clear economic rationale. While considerable gains from trade due to comparative advantage are foregone because many products are excluded-most notably agricultural imports from the ASEAN partners - the agreements have an important economic motivation. Building on models that focus on the role of economies of scale, I have posited that horizontal and vertical differentiations in such industries play a crucial role in the agreements studied here. If this is the key economic benefit behind the PTAs, then we would expect lobbying demands to focus on the liberalization of differentiated goods. Moreover, the tariff liberalization patterns in the PTAs should closely reflect these interests. Horizontally and vertically differentiated export goods produced by industries with economies of scale should receive greater preferential margins than inter-industry exports. Conversely, inter-industry trade based on different factor endowments or natural comparative advantage should be most likely excluded from an agreement. The qualitative and quantitative evidence in this article supports this explanation. In the case of the Japan-Malaysia PTA, industry demands focused specifically on liberalization in these sectors. Bargains between the Japanese and Malaysian governments revolved around trade-offs in these sectors as well. Evidence for the "demand side" of the explanation is therefore clear. 
The "supply side," that is, the actual liberalization in the agreements, is amenable to quantitative analysis. I find that the tariff margins in the PTAs negotiated by Japan and South Korea with the major ASEAN partners closely reflect the character of the industry-much like the demand side would suggest. Tariff preferences are considerably greater compared to MFN duties when goods are part of intraindustry trade. Inter-industry trade, on the other hand, is more likely to be excluded from the agreement. The export orientation and the extent of import competition of an industry appear to have effects on tariff reductions that resonate with the specific factor model. While they are not at the heart of the analysis, they provide further evidence that the patterns of tariff reduction in Japan's and South Korea's PTAs with ASEAN partners reflect economic interests.

These findings are inconsistent with claims that PTAs in Asia Pacific are a purely political phenomenon with little economic relevance. Even if the agreements have had proponents among policymakers, it is highly unlikely that PTAs would systematically reflect the interests of important industries engaged in trade between the partner countries if only government agencies were behind the deals. At least for Japanese and South Korean PTAs with their Southeast Asian partners, the economic interests have a direct relationship with the character of tariff liberalization in the agreements.

These arguments are likely to travel well to other "North-South" agreements in the Asia-Pacific region. At the same time, there are clear limitations: economies of scale are an unlikely driving force of PTAs such as the Japan-Australia agreement-but then the lengthy negotiations suggest that a reciprocal bilateral agreement between two countries with such different endowments is difficult. Moreover, some developing countries in the Asia-Pacific region use the Enabling Clause to negotiate agreements that do not require any liberalization - the Chile-India PTA is a case in point-while others may sign PTAs but then let them languish (Gray 2014).

My argument in this article also speaks to a wider debate on the political economy of PTAs beyond the Asia-Pacific region. The article is among a small number of studies that present evidence for the importance of intra-industry trade not only in PTA formation in general, but also in the design of agreements. It also suggests that preferential trade agreements do not have to have widespread benefits to be viable-in fact, they almost have private goods character if they primarily benefit larger firms in capital-intensive sectors of production. The exclusion of agriculture in particular also suggests that 
PTAs in Asia Pacific are not a substitute for progress at the WTO. Although at this point it seems clear that PTAs will "form part of the long-term tapestry of international trade relations," as Pascal Lamy (2012), former WTO director-general, writes, their design is far from economically optimal. In this sense the critics of PTAs in Asia Pacific are right: to reap greater gains from trade, much more liberalization would be required.

Mark S. Manger is assistant professor of political economy and global affairs at the Munk School at the University of Toronto. His research interests include trade and investment policy in Asia Pacific and the political economy of Japan. $\mathrm{He}$ is the author of Investing in Protection: The Politics of Preferential Trade Agreements Between North and South (2009), and of articles in International Studies Quarterly, Journal of Conflict Resolution, Review of International Political Economy, World Development, and World Politics.

\section{Appendix}

\section{Table A1 Data Sources}

\begin{tabular}{ll}
\hline Variable & Source \\
\hline $\begin{array}{l}\text { Vertical and horizontal } \\
\text { intra-industry trade }\end{array}$ & BACI Database \\
Tariff data & WITS and manual coding from PTA schedules \\
Industry data & UNIDO \\
\hline
\end{tabular}

Table A2 Summary Statistics

\begin{tabular}{lccccc}
\hline Variable & Observations & Mean & Std. Dev. & Minimum & Maximum \\
\hline Exclusion & 18,865 & 0.011 & 0.103 & 0 & 1 \\
HIIT & 18,865 & 0.081 & 0.273 & 0 & 1 \\
VIIT & 18,865 & 0.321 & 0.467 & 0 & 1 \\
lnExports & 18,865 & 3.970 & 2.70 & -6.996 & 13.984 \\
ImportCompetition & 18,865 & 0.266 & 0.189 & 0.0003 & 0.840 \\
\hline
\end{tabular}


Table A3 Insignificant Variables Dropped from Models

\begin{tabular}{|c|c|c|}
\hline Variable & Operationalization & Source \\
\hline $\begin{array}{l}\text { Real output of industry in } \\
\text { exporting country }\end{array}$ & $\begin{array}{l}\text { As is in constant } 2005 \text { USD } \\
\text { or in log form }\end{array}$ & UNIDO \\
\hline $\begin{array}{l}\text { Real output of industry in } \\
\text { importing country }\end{array}$ & $\begin{array}{l}\text { As is in constant } 2005 \text { USD } \\
\text { or in log form }\end{array}$ & UNIDO \\
\hline $\begin{array}{l}\text { Real consumption of industry } \\
\text { products in exporting country }\end{array}$ & $\begin{array}{l}\text { As is in constant } 2005 \text { USD } \\
\text { or in log form }\end{array}$ & UNIDO \\
\hline $\begin{array}{l}\text { Real consumption of industry } \\
\text { products in importing country }\end{array}$ & $\begin{array}{l}\text { As is in constant } 2005 \text { USD } \\
\text { or in log form }\end{array}$ & UNIDO \\
\hline \multirow{2}{*}{$\begin{array}{l}\text { Number of employees in } \\
\text { industry in exporting country }\end{array}$} & As is & UNIDO \\
\hline & As is & UNIDO \\
\hline \multicolumn{3}{|l|}{$\begin{array}{l}\text { Number of employees in } \\
\text { industry in importing country }\end{array}$} \\
\hline $\begin{array}{l}\text { Real total imports by importing } \\
\text { country }\end{array}$ & $\begin{array}{l}\text { As is in constant } 2005 \text { USD } \\
\text { or in log form }\end{array}$ & UNIDO \\
\hline $\begin{array}{l}\text { Real total exports by exporting } \\
\text { country }\end{array}$ & $\begin{array}{l}\text { As is in constant } 2005 \text { USD } \\
\text { or in log form }\end{array}$ & UNIDO \\
\hline $\begin{array}{l}\text { Number of firms in industry in } \\
\text { importing country }\end{array}$ & As is & UNIDO \\
\hline $\begin{array}{l}\text { Number of firms in industry in } \\
\text { exporting country }\end{array}$ & As is & UNIDO \\
\hline $\begin{array}{l}\text { Export orientation of industry } \\
\text { in exporting country }\end{array}$ & $\begin{array}{l}\text { Exports of industry/ } \\
\text { total output of industry }\end{array}$ & UNIDO \\
\hline $\begin{array}{l}\text { Industrial concentration of } \\
\text { industry in importing country }\end{array}$ & $\begin{array}{l}\text { Total output of industry/ } \\
\text { number of firms }\end{array}$ & UNIDO \\
\hline GDP ratio & $\begin{array}{l}\mathrm{GDP}_{i} / \mathrm{GDP}_{j} \text { in current } \\
\text { or constant USD }\end{array}$ & $\begin{array}{l}\text { World } \\
\text { Development } \\
\text { Indicators }\end{array}$ \\
\hline $\begin{array}{l}\text { GDP per capita of exporter } \\
\text { or importer }\end{array}$ & $\begin{array}{l}\text { GDP per capita in current } \\
\text { or constant USD }\end{array}$ & $\begin{array}{l}\text { World } \\
\text { Development } \\
\text { Indicators }\end{array}$ \\
\hline
\end{tabular}

\section{Notes}

The author thanks Kilian Huber for excellent research assistance, Ann Capling and Rob Franzese for detailed advice on the article, and audience members at the OCIS 2010, ISA Asia Pacific 2011, and MPSA 2012 conferences for their comments. The research leading to these results has received funding from the European Community's Seventh Framework Programme (FP7/2007-2013) under grant agreement no. PIRG05-GA 2009-247836.

1. Important exceptions are the China-Taiwan Economic Cooperation Framework Agreement and the US-Vietnam Trade Agreement as partial-scope PTAs (i.e., agreements that only liberalize some sectors).

2. But note the South Korea-Chile PTA: South Korea is classified as a developing country in the WTO and has opted for the Enabling Clause in some 
PTAs. Chile, despite a lower per capita GDP, insists on referring to Article 24 in its PTAs.

3. Baccini and Dür (2012) are thus right to stress that their study explains the "new regionalism."

4. The increase of intra-industry trade has been cited as a cause of successful global trade liberalization in manufactured goods (Krugman 1981). Gilligan (1997) notes that lobbying becomes a "private good" because adjustment costs are specific to the firm; however, Kono (2009) finds little empirical evidence of this.

5. Technically, the unit value data are missing much more frequently for countries that exhibit low intra-industry trade values in their nonmissing trade data, indicating that these values are not missing at random. Using these data would create a strong bias in the analysis, in addition to resulting in imprecise estimates.

6. Of course, East Asian states have been characterized as "strong" or "developmentalist" and enjoying significant autonomy (Deyo 1987; Johnson 1982; Woo-Cumings 1999). But it is incongruent to claim that a state is independent while at the same time acknowledging that it is selectively but strongly protectionist of import-competing sectors like agriculture. This does not mean that policies are always the result of private sector initiatives. Government officials can obviously propose policies, including PTAs, even if no specific demand has been voiced by the private sector.

7. Straits Times (Singapore), "KL Hastens to Seal FTA with Japan," July 4, 2003 (www.straitstimes.com, accessed October 18, 2013).

8. Kyodo News Agency, "Malaysia, Japan May Reach Free-Trade Pact by Year-End," July 17, 2003 (accessed through www.factiva.com, October 18, 2013).

9. Nihon Kōgyō Shimbun, "Kyō kara Tōkyō de seifukan kyōgi, Mareshia to FTA teiketsu, SARS taiōmo sekyo gidaini" [Government-level talks kick off in Tokyo today; Malaysia FTA conclusion, urgent response to SARS on the agenda], May 8, 2003, p. 24.

10. Nikkan Kōgyō Shimbun, "Nippon to Mareshia, FTA kōshō ōsuji gōi heTai to no kōshōni mo kōueikyō ga" [Japan-Malaysia: FTA negotiations move toward agreement on draft text; favorable influence on negotations with Thailand], May 23, 2005, p. 2; Fuji Sankei Business, "Nippon, Mareshia FTA gōi, kanmin de jidōsha gijutsu shien" [Japan, Malaysia FTA to include support for automotive technology, officials say], May 23, 2005, p. 2.

11. Bernama News, "Rafidah: Open Market Will Not Hurt Local Auto Industry," December 10, 2005 (accessed through www.factiva.com, October 18, 2013).

12. Today Newspaper (Singapore), "Japan, M'sia Begin New FTA Talks," May 17, 2005 (accessed through www.factiva.com, April 28, 2007).

13. Economist Intelligence Unit, "Japan/Malaysia: Green Light for Trade Pact," May 23, 2005.

14. Steel Business Briefing, "Japan Steelmakers Hail Japan-Malaysia Free Trade Pact," July 18, 2006 (accessed through www.factiva.com, October 18, 2013).

15. Bernama News, "Abdullah and Koizumi Agree on JMEPA, to Be Formalised in December," May 25, 2005 (accessed through www.factiva.com, October 18, 2013). 
16. All replication data and code are available from the author's Dataverse at http://thedata.harvard.edu/dvn/dv/markmanger.

17. Hale (2011) shows that prior to the formation of PTAs, East Asian countries often applied tariffs much lower than the rates at which these were "bound" in WTO commitments. By contrast, the present study focuses on the elimination of these remaining applied tariffs. Note, however, that even if there were no preferential margin between applied rates and PTA rates, the contracting parties would at least lock in these rates and lose the ability to raise tariffs again in times of economic difficulties.

18. A tariff-rate quota (TRQ) provides for a limited import volume at a lower tariff, and a much higher tariff when the quota is exceeded. TRQs are common for agricultural products, and often result in higher prices once the quota is exceeded than those charged by domestic producers in the importing country. In other words, they are often insurmountable barriers.

19. This classification is referred to as "threshold method" in applied economics literature. Theoretically, more precise alternatives use hedonic pricing (Cooper, Greenaway, and Rayner 1993) or price elasticities (Brenton and Winters 1992), but the necessary data are not available for developing countries. See Flam and Helpman (1987) for further discussion of the underlying theory. For important applications of the decomposition into trade types using thresholds see Fukao, Ishido, and Ito (2003) and Kimura and Ando (2005).

20. Although Japan often specifies individual subcategories, these are usually not defined as HS6 codes. These "special categories" are prevalent in agricultural products, where individual species and plants are listed. If there are tariff differences between the HS6 code and the verbally specified tariff category, I take the unweighted average.

21. In 2010, fifty-seven cars were exchanged for $792 \mathrm{~kg}$ of not further defined "preserved preparations of bovine animals, incl. mixtures" from Japan, according to COMTRADE (http://comtrade.un.org) data.

22. See www.cepii.fr/anglaisgraph/bdd/baci/non_restrict/sector.asp (accessed March 12, 2012).

23. Results for the inclusion of annual values for the controls instead of moving averages are available from the author on request.

24. Available at www.markmanger.net/published-work/.

25 . Technically speaking this is a latent variable because theoretically the "desired" tariff could be negative, but this is in practice not possible, so we only observe zeros.

26. See Bischof (2009) for a readable comparison of standard procedures for "robust" standard errors with a simple bootstrap, and Efron and Tibshirani (1998) for a more technical introduction. The procedure is particularly useful as many tariffs are zero for some countries because the good is neither produced in these countries nor traded between them, so the data are highly skewed.

27. Recall that while we can interpret a Tobit coefficient like a coefficient in an OLS regression, the linear effect is on the uncensored latent variable, not the observed outcome (McDonald and Moffitt 1980). 


\section{References}

Abd-el-Rahman, Kamal. 1991. "Firms Competitive and National Comparative Advantages as Joint Determinant of Trade Composition." Weltwirtschaftliches Archiv 127, 1: 83-97.

Achen, Christopher H. 2002. "Toward a New Political Methodology: Microfoundations and ART." Annual Review of Political Science 5, 1: 423-450.

Aggarwal, Vinod K. 1994. "Comparing Regional Cooperation Efforts in the Asia-Pacific and North America." In Pacific Cooperation: Building Economic and Security Regimes in the Asia-Pacific Region, ed. Andrew Mack and John Ravenhill, 40-65. St. Leonards, NS: Allen and Unwin.

Aggarwal, Vinod K., and Shujiro Urata. 2006. Bilateral Trade Arrangements in the Asia-Pacific: Origins, Evolution, and Implications. London: Routledge.

Alfaro, Laura, and Andrew Charlton. 2009. "Intra-Industry Foreign Direct Investment." American Economic Review 99, 5: 2096-2119.

Athukorala, Prema-chandra. 2005. "Trade Policy in Malaysia: Liberalization Process, Structure of Protection, and Reform Agenda." ASEAN Economic Bulletin 22, 1: 19-34.

- 2010. "Production Networks and Trade Patterns in East Asia: Regionalization or Globalization?" ADB Working Paper Series on Regional Economic Integration 56. Manila: Asian Development Bank.

Baccini, Leonardo, and Andreas Dür. Forthcoming. "Investment Discrimination and the Proliferation of Preferential Trade Agreements." Journal of Conflict Resolution.

- 2012. "The New Regionalism and Policy Interdependence." British Journal of Political Science 42, 1: 57-79.

Baier, Scott L., and Jeffrey H. Bergstrand. 2004. "Economic Determinants of Free Trade Agreements.” Journal of International Economics 64, 1: 29-63.

Baldwin, Richard E. 1996. "A Domino Theory of Regionalism.” In Expanding Membership of the European Union, ed. Richard E. Baldwin, Pertti Haaparanta, and Jaakko Kiander, 25-48. Cambridge: Cambridge University Press.

Baldwin, Richard E., Rikard Forslid, and Jan I. Haaland. 1996. "Investment Creation and Diversion in Europe." World Economy 19, 6: 635-659.

Bergsten, C. Fred. 1997. "Open Regionalism.” World Economy 20, 5: 545-565.

Bischof, Jonathan M. 2009. "A Bootstrap Approach to Time Invariance in Panel Data." Paper presented at the Annual Meeting of the American Political Science Association, Chicago, September 1-4.

Borrus, Michael G., Dieter Ernst, and Stephan Haggard. 2000. International Production Networks in Asia: Rivalry or Riches? London: Routledge.

Brenton, Peter A., and L. Alan Winters. 1992. "Estimating the International Trade Effects of '1992': West Germany.” Journal of Common Market Studies 30, 2: $143-156$.

Capling, Ann. 2008. "Preferential Trade Agreements as Instruments of Foreign Policy: An Australia-Japan Free Trade Agreement and Its Implications for the Asia Pacific Region." Pacific Review 21, 1: 27-43.

Centre d'Etudes Prospectives et d'Informations Internationales (CEPII). 2010. BACI: International Trade Database at the Product-Level. The 1994-2007 Version. www.cepii.fr/anglaisgraph/bdd/baci.htm. 
Chase, Kerry A. 2003. "Economic Interests and Regional Trading Arrangements: The Case of NAFTA." International Organization 57, 1: 137-174.

Cooper, Douglas, David Greenaway, and Anthony J. Rayner. 1993. "IntraIndustry Trade and Limited Producer Horizons: An Empirical Investigation." Review of World Economics 129, 2: 345-366.

Davis, Christina L. 2004. "International Institutions and Issue Linkage: Building Support for Agricultural Trade Liberalization." American Political Science Review 98, 1: 153-169.

Dent, Christopher M. 2003. "Networking the Region? The Emergence and Impact of Asia-Pacific Bilateral Free Trade Agreement Projects." Pacific Review 16, 1: 1-28.

Deyo, Frederic C. 1987. The Political Economy of the New Asian Industrialism. Ithaca, NY: Cornell University Press.

Efron, Bradley, and Robert J. Tibshirani. 1998. An Introduction to the Bootstrap. Boca Raton, FL: CRC Press.

Feenstra, Robert C. 2004. Advanced International Trade: Theory and Evidence. Princeton, NJ: Princeton University Press.

Finlayson, Jock A., and Mark W. Zacher. 1981. "The GATT and the Regulation of Trade Barriers: Regime Dynamics and Function." International Organization 35, 4: 561-602.

Flam, Harry, and Elhanan Helpman. 1987. "Vertical Product Differentiation and North-South Trade." American Economic Review 77, 5: 810-822.

Fontagné, Lionel, and Michael Freudenberg. 1997. "Intra-Industry Trade: Methodological Issues Reconsidered.” Paris: Centre d'Etudes Prospectives et d'Informations Internationales (CEPII).

Fontagné, Lionel, Michael Freudenberg, and Guillaume Gaulier. 2005. "Disentangling Horizontal and Vertical Intra-Industry Trade.” Paris: CEPII.

Fukao, Kyoji, Hikari Ishido, and Keiko Ito. 2003. "Vertical Intra-Industry Trade and Foreign Direct Investment in East Asia." Tokyo: Research Institute of the Ministry of Economy, Trade, and Industry (RIETI).

Gallant, Nicole, and Richard Stubbs. 1997. "APEC's Dilemmas: InstitutionBuilding Around the Pacific Rim." Pacific Affairs 70, 2: 203-218.

Gilligan, Michael J. 1997. "Lobbying as a Private Good with Intra-Industry Trade." International Studies Quarterly 41, 3: 455-474.

Gowa, Joanne, and Edward D. Mansfield. 1993. "Power-Politics and International Trade." American Political Science Review 87, 2: 408-420.

Gray, Julia. 2014. "Life, Death, or Zombies? The Survival and Revival of Regional Organizations." Paper presented at the Political Economy of International Organizations Conference, Niehaus Center for Globalization and Governance, Princeton University, Princeton, NJ, January 16-18.

Greenaway, David, Robert Hine, and Chris Milner. 1994. "Country-Specific Factors and the Pattern of Horizontal and Vertical Intra-Industry Trade in the UK." Weltwirtschaftliches Archiv 130, 1: 77-100.

Grieco, Joseph M. 1997. "Systemic Sources of Variation in Regional Institutionalization in Western Europe, East Asia, and the Americas." In The Political Economy of Regionalism, ed. Edward D. Mansfield and Helen V. Milner, 164-187. New York: Columbia University Press. 
Grossman, Gene M., and Elhanan Helpman. 1994. "Protection for Sale." American Economic Review 84, 4: 833-850.

Hale, Thomas. 2011. "The de Facto Preferential Trade Agreement in East Asia." Review of International Political Economy 18, 3: 299-327.

Hayakawa, Kazunobu. 2011. "Measuring Fixed Costs for Firms' Use of a Free Trade Agreement: Threshold Regression Approach." Economics Letters 113, 3: 301-303.

Hayakawa, Kazunobu, Hansung Kim, and Hyun-hoon Lee. 2013. "Determinants on Utilization of the Korea-ASEAN Free Trade Agreement: Margin Effect, Scale Effect, and ROO Effect." World Trade Review FirstView.

Hicks, Raymond, and Soo Yeon Kim. 2012. "Reciprocal Trade Agreements in Asia: Credible Commitment to Trade Liberalization or Paper Tigers?" Journal of East Asian Studies 12, 1: 1-29.

Higgott, Richard A., Richard Leaver, and John Ravenhill. 1993. Pacific Economic Relations in the 1990s: Cooperation or Conflict? Boulder, CO: Lynne Rienner.

Hiratsuka, Daisuke. 2011. "Production Networks in Asia: A Case Study from the Hard Disk Drive Industry.” ADBI Working Paper Series 301. Tokyo: Asian Development Bank Institute.

Japan Business Council for Trade and Investment Facilitation. 2003. Issues and Requests Relating to Trade and Investment in 2003. Tokyo: Japan Business Council for Trade and Investment Facilitation.

Johnson, Chalmers A. 1982. MITI and the Japanese Miracle: The Growth of Industrial Policy, 1925-1975. Stanford, CA: Stanford University Press.

Kahler, Miles. 1994. "Institution-Building in the Pacific." In Pacific Cooperation: Building Economic and Security Regimes in the Asia-Pacific Region, ed. Andrew Mack and John Ravenhill, 16-39. St. Leonards, NS: Allen and Unwin.

Katada, Saori N., Mireya Solís, and Barbara Stallings. 2009. Competitive Regionalism: Explaining the Diffusion of FTAs in the Pacific Rim. London: Palgrave.

Katzenstein, Peter J., and Takashi Shiraishi. 2006. Beyond Japan: The Dynamics of East Asian Regionalism. Ithaca, NY: Cornell University Press.

Kim, Soo Yeon. 2014. "Negotiating the Nexus: Production Networks and Behindthe-Border Commitments in RTAs." Paper presented at the Political Economy of International Organizations Conference, Niehaus Center for Globalization and Governance, Princeton University, Princeton, NJ, January 16-18.

Kimura, Fukunari, and Mitsuyo Ando. 2005. "Two-Dimensional Fragmentation in East Asia: Conceptual Framework and Empirics." International Review of Economics and Finance 14, 3: 317-348.

Kiyota, Kozo. 2006. "Why Countries Are So Eager to Establish Bilateral Free Trade Agreements: A Case Study of Thailand." In Bilateral Trade Agreements in the Asia-Pacific: Origins, Evolution, and Implications, ed. Vinod K. Aggarwal and Shujiro Urata, 206-231. London: Routledge.

Kono, Daniel Y. 2009. "Market Structure, Electoral Institutions, and Trade Policy.” International Studies Quarterly 53, 4: 885-906. 
Krauss, Ellis S. 2003. "The US, Japan, and Trade Liberalization: From Bilateralism to Regional Multilateralism to Regionalism." Pacific Review 16, 3: 307-329.

Krugman, Paul R. 1981. "Intraindustry Specialization and the Gains from Trade." Journal of Political Economy 89, 5: 959-973.

Lamy, Pascal. 2012. "Foreword by the WTO Director-General." In World Trade Report 2011: The WTO and Preferential Trade Agreements: From CoExistence to Coherence, 3-4. Geneva: World Trade Organization.

Manger, Mark S. 2005. "Competition and Bilateralism in Trade Policy: The Case of Japan's Free Trade Agreements.” Review of International Political Economy 12, 5: 804-828.

-2009. Investing in Protection: The Politics of Preferential Trade Agreements Between North and South. Cambridge: Cambridge University Press.

- 2012. "Vertical Trade Specialization and the Formation of North-South PTAs." World Politics 64, 4: 622-658.

Mansfield, Edward D., and Rachel Bronson. 1997. "Alliances, Preferential Trading Arrangements, and International Trade." American Political Science Review 91, 1: 94-107.

Mansfield, Edward D., and Helen V. Milner. 2010. "Regime Type, Veto Points, and Preferential Trading Arrangements." Stanford Journal of International Law 46, 2: 219-242.

Mansfield, Edward D., Helen V. Milner, and B. Peter Rosendorff. 2002. "Why Democracies Cooperate More: Electoral Control and International Trade Agreements." International Organization 56, 3: 477-513.

Mansfield, Edward D., and Eric Reinhardt. 2003. "Multilateral Determinants of Regionalism: The Effects of GATT/WTO on the Formation of Preferential Trading Arrangements." International Organization 57, 4: 829-862.

- 2008. "International Institutions and the Volatility of International Trade." International Organization 62, 4: 621-652.

Mason, Amy M. 2004. "The Degeneralization of the Generalized System of Preferences (GSP): Questioning the Legitimacy of the US GSP." Duke Law Journal 54, 2: 513-547.

McDonald, John F., and Robert A. Moffitt. 1980. "The Uses of Tobit Analysis." Review of Economics and Statistics 62, 2: 318-321.

Milner, Helen V. 1997. "Industries, Governments, and the Creation of Regional Trade Blocs." In The Political Economy of Regionalism, ed. Edward D. Mansfield and Helen V. Milner, 77-106. New York: Columbia University Press.

Milner, Helen V., and Keiko Kubota. 2005. "Why the Move to Free Trade? Democracy and Trade Policy in the Developing Countries." International Organization 59, 1: 107-143.

Munakata, Naoko. 2001. "Evolution of Japan's Policy Toward Economic Integration." Washington, DC: Center for Northeast Asian Policy Studies (CNAPS), The Brookings Institution.

Nelson, Douglas. 1988. "Endogenous Tariff Theory: A Critical Survey." American Journal of Political Science 88, 3: 796-838. 
Nishitateno, Shuhei. 2013. "Global Production Sharing and the FDI-Trade Nexus: New Evidence from the Japanese Automobile Industry." Journal of the Japanese and International Economies 27, 1: 64-80.

Ogita, Tatsushi. 2002. "An Approach Towards Japan's FTA Policy." Chiba: Institute of Developing Economies, Japan External Trade Organization.

_ 2003. "Japan as a Late-Coming FTA Holder: Trade Policy Change for Asian Orientation?" In Wither Free Trade Agreements? Proliferation, Evaluation, and Multilateralization, ed. Jiro Okamoto, 216-251. Chiba: Institute of Developing Economies, Japan External Trade Organization.

Pekkanen, Saadia M. 2005. "Bilateralism, Multilateralism, or Regionalism? Japan's Trade Forum Choices." Journal of East Asian Studies 5, 1: 77-103.

Pekkanen, Saadia M., Mireya Solís, and Saori N. Katada. 2007. "Trading Gains for Control: International Trade Forums and Japanese Economic Diplomacy.” International Studies Quarterly 54, 4: 945-970.

Pempel, T. J. 2006. "The Race to Connect East Asia: An Unending Steeplechase." Asian Economic Policy Review 1, 2: 239-254.

Ravenhill, John. 2006. "The Political Economy of the New Asia-Pacific Bilateralism: Benign, Banal, or Simply Bad?" In Bilateral Trade Agreements in the Asia Pacific: Origins, Evolution, and Implications, ed. Vinod K. Aggarwal and Shujiro Urata, 27-49. London: Routledge.

_ 2010. "The 'New East Asian Regionalism': A Political Domino Effect." Review of International Political Economy 17, 2: 178-208.

Schrodt, Philip. 2010. "Seven Deadly Sins of Contemporary Quantitative Political Analysis." Paper presented at the Annual Meeting of the American Political Science Association, Washington, DC, September 2-5.

Sekizawa, Yoichi. 2008. "Nihon No FTA Seisaku: Sono Seiji Katei No Bunseki" [Japan's FTA policy: Analysis of the political process]. ISS Research Series 26. Tokyo: Institute of Social Science, University of Tokyo.

Solís, Mireya. 2003. "Japan's New Regionalism: The Politics of Free Trade with Mexico." Journal of East Asian Studies 3, 3: 377-404.

Takahashi, Katsuhide, and Shujiro Urata. 2010. "On the Use of FTAs by Japanese Firms: Further Evidence." Business and Politics 12, 1: 1-17.

Woo-Cumings, Meredith. 1999. The Developmental State. Ithaca, NY: Cornell University Press.

WTO. 2011. "World Trade Report 2011: The WTO and Preferential Trade Agreements: From Co-Existence to Coherence." Geneva: World Trade Organization.

Yoshimatsu, Hidetaka. 2005. "Japan's Keidanren and Free Trade Agreements: Societal Interests and Trade Policy.” Asian Survey 45, 2: 258-278. 